Research Article

\title{
Political Risk Paths in International Construction Projects: Case Study from Chinese Construction Enterprises
}

\author{
Tengyuan Chang $\mathbb{D}^{1}{ }^{1}$ Xiaopeng Deng $\mathbb{D}^{1},{ }^{1}$ Bon-Gang Hwang, ${ }^{2}$ and Xiaojing Zhao ${ }^{2}$ \\ ${ }^{1}$ School of Civil Engineering, Southeast University, Si Pai Lou, Nanjing 210096, China \\ ${ }^{2}$ Department of Building, National University of Singapore, 4 Architecture Drive, Singapore117566,
}

Correspondence should be addressed to Xiaopeng Deng; dxp@seu.edu.cn

Received 7 April 2018; Revised 25 June 2018; Accepted 19 July 2018; Published 7 August 2018

Academic Editor: Dujuan Yang

Copyright (C) 2018 Tengyuan Chang et al. This is an open access article distributed under the Creative Commons Attribution License, which permits unrestricted use, distribution, and reproduction in any medium, provided the original work is properly cited.

International construction enterprises (ICEs) have been plagued with political risks in the global market. To ensure the success of political risk management, it is necessary to comprehend the political risks in international construction projects. This study aims at exploring the political risk paths in international construction projects. The preliminary political risk factors and paths were proposed from the literature review. A survey questionnaire was developed to collect political risk cases faced by Chinese construction enterprises (CCEs) performing international construction projects, and 264 valid cases were received and analyzed for this study. Adopting the confirmatory factor analysis (CFA) method, 6 macrofactors ("sociopolitical stability" (A), "legal and regulatory" (B), "social safety" (C), "economy performance" (D), "attitude towards foreigners" (E), and "international environment" (F)) and 2 microfactors ("low exposure" $(\mathrm{G})$ and "capability of enterprises" $(\mathrm{H})$ ) were identified. Moreover, the results of path analysis illustrated that 7 factors (A, B, C, D, E, G, and H) had the significant direct negative effect on "risk consequences" and 3 factors ( $\mathrm{A}, \mathrm{D}$, and $\mathrm{F}$ ) had the indirect negative effect on "risk consequences." The findings from this study help practitioners gain an in-depth understanding of political risks in international construction projects and provide a useful reference for ICEs to manage political risks when venturing outside their home countries.

\section{Introduction}

As China joined World Trade Organization (WTO) and the local construction market has reached the saturation point, many well-known Chinese construction enterprises (CCEs) began to carry out construction works in overseas projects [1]. According to the data of Engineering News-Record (ENR), the revenues of Chinese contractors increased from $\$ 8.8$ billion in 2004 to $\$ 98.7$ billion in 2016, with the first ranking in the world, and 65 Chinese contractors were included in the ENR's top 250. With the proposition of Silk Road Economic Belt strategy, more and more CCEs will step abroad to expand their market worldwide [2].

However, despite the tremendous opportunities, CCEs have also witnessed a dramatic increase in political risks around the world, particularly in developing countries [3]. In 2015, three executives of the China Railway Construction Corporation were killed in the Mali terrorist attack. In 2014, the Mexican government annulled a business deal with a Chinese-led consortium over its first high-speed railway project due to public concerns about the bidding process. In 2012, in the armed conflict between Sudanese rebels and the local government, 29 Sinohydro staff members in a highway project were kidnapped by Sudanese rebels. Political risks have brought huge losses to CCEs and will be a persistent obstacle to the development of the Chinese overseas construction business.

With consideration of the negative and significant impact of political risks on international construction projects, how to effectively manage political risks has become a hot issue for international construction business [4]. The participants of international construction projects come from different countries with different values, religions, habits, customs, and codes of conduct. Compared to domestic construction projects, international construction projects are more vulnerable to political risks [5]. Successful political risk management is inseparable from a thorough understanding of political risks. International construction 
enterprises (ICEs) should fundamentally master the knowledge of political risk management before marching into the overseas market $[3,6]$. Political risk is the result of the interaction of a series of driving factors [7]. To achieve success in political risk management practices, it is necessary for ICEs to identify these factors and their interrelationships.

It should be noted that the political risks ICEs confronted in the global market are obviously different from that of traditional multinational enterprises. Exporting goods and services are the main business of ICEs. Due to the lack of capital investment, ICEs do not have the exposures that arising from establishment and maintenance of a production facility [8]. Moreover, ICEs are not resource-based enterprises, so they rarely encounter conflicts with local governments and organizations who are concerned with natural resources [5]. In most cases, international construction business is project-specific. ICEs are concerned primarily with the stability of their expected returns in a short time period. Therefore, they are extremely sensitive to environmental fluctuations that can severely influence project cash flow.

Nonetheless, the existing literature mainly focused on the political risks arising from international general business (e.g., foreign direct investment, trade in goods, and international joint ventures) of traditional multinational enterprises and paid less attention on the political risks residing in international construction business. Since international construction business and international general business have different political risks [5], the theory of political risk associated with the international general business maybe not completely appropriate to the international construction business. As a result, the specific objectives of this study are (1) to identify the political risk paths in international construction projects and (2) to examine the significance of those risk paths.

As less attention has been paid to political risk management in the international construction business, this study can contribute to the existing body of knowledge. Furthermore, when ICEs venture outside their home countries, the findings from this study can assist ICEs by providing a reference in clearly understanding the political risk arising from the international construction business as well as their relative relationships represented by risk paths.

\section{Background}

The definitions of political risk can be mainly split into two groups $[4,9]$. The first approach emphasized the causes of political risk while regarded political risk as the possibility of the adverse consequences produced by political events (e.g., wars, regime changes, revolutions, political violence, riots, insurrections, terrorist attacks, and coups) and government activities (e.g., expropriations, unfair compensations, foreign exchange restrictions, illegal interferences, changes in laws, corruption, poor enforcement of the contract, and labor restrictions) [10, 11]. The second approach focused on the consequences of political risk and defined political risk as negative impacts on enterprises due to the deterioration of political environment $[12,13]$.
Combining the two aforementioned approaches, political risk in international construction projects can be defined as the uncertainty of political events and arbitrary or discriminatory actions by host governments or political groups that might have adverse effects on the objectives of ICEs.

Risk factors can be defined as variables influencing risk increase or decrease [14]. Some studies identified a list of political risk factors. For example, Jakobsen maintained that obsolescing bargain mechanism, sociopolitical instability and grievances, political institutions, and preferences and attitudes are the main political risk factors in international business [15]. Tsai and $\mathrm{Su}$ established a political risk assessment model for port projects and grouped political risk factors into five categories: project development policy, project management policy, foreign enterprise policy, political and social systems, and macroeconomic practices [16]. Moreover, some studies have examined political risk factors in international construction projects. For example, Deng and Low identified the political risks in international construction projects and categorized 85 political risk factors into five levels: international environment, host country, industry-specific, project-specific, and firm-specific [7]. Deng et al. stated that political risk in international projects bursts when external threats and internal vulnerability overlap and concluded that the internal vulnerability of project systems are determined by the characteristics of projects and firms [17]. These studies shared a common shortcoming that they overlooked the causal relationships among political factors and consequences.

In this study, a total of 29 political risk factors and 3 political risk consequences were identified from a comprehensive review of the relevant literature. To verify the comprehensiveness of the identified risk factors and consequences, a pilot survey was performed with a few experts to collect their opinions on the preliminary list of the risk factors and consequences. These experts were (1) five Chinese professors who focused on international project management and political risk management and (2) five senior managers who came from five CCEs (China Communications Construction Group Limited, Power Construction Corporation of China, China State Construction Engineering Corporation, and China Railway Group Limited). All of the 10 experts had more than 20 years of work experience. Based on the pilot survey, the 29 political risk factors and 3 political risk consequences were divided into nine groups (i.e., Groups A to I) (Table 1): "sociopolitical stability" (A1-A3), "legal and regulatory" (B1-B5), "social safety" (C1-C5), "economy performance" (D1-D4), "attitude towards foreigners" (E1-E3), "international interactive relations" (F1-F3), "low exposure" (G1-G3), "capability of enterprises" (H1-H3), and "risk consequences" (I1-I3).

Some studies have discussed the relationships among political risk factors. For example, Annett deemed that government instability can result in poor legislation and regulation and thereby increase the political risk [18]. Rice and Mahmoud argued that economy performance of the host country has strong relationships with sociopolitical stability and public safety [29]. Yaprak and Sheldon believed that international environment can affect the host country's 
TABle 1: Political risk factors and consequences in international construction projects.

\begin{tabular}{|c|c|c|}
\hline Grouping & Factors & References \\
\hline \multirow{3}{*}{$\begin{array}{l}\text { A: sociopolitical } \\
\text { stability }\end{array}$} & A1: government unity & {$[7,18,19]$} \\
\hline & A2: factional conflicts & {$[7,18,19]$} \\
\hline & A3: religious and ethnic tensions & {$[7,18,19]$} \\
\hline \multirow{5}{*}{$\begin{array}{l}\text { B: legal and } \\
\text { regulatory }\end{array}$} & B1: poor enforcement mechanisms & {$[7,20,21]$} \\
\hline & B2: policy uncertainty & {$[4,5,21]$} \\
\hline & B3: unfairness of judicial process & {$[7,20,22]$} \\
\hline & B4: price controls & {$[4,5]$} \\
\hline & B5: speediness of judicial process & {$[7,20]$} \\
\hline \multirow{5}{*}{ C: social safety } & C1: crime & {$[4,23]$} \\
\hline & C2: terrorism & {$[4,23]$} \\
\hline & C3: violent demonstrations & {$[4,23]$} \\
\hline & C4: armed conflicts & {$[4,23]$} \\
\hline & C5: kidnapping or extortion & {$[4,23]$} \\
\hline \multirow{4}{*}{$\begin{array}{l}\text { D: economy } \\
\text { performance }\end{array}$} & D1: inflation & {$[5,24,25]$} \\
\hline & D2: unemployment & {$[5,24,25]$} \\
\hline & D3: exchange rate volatility & {$[5,24,25]$} \\
\hline & D4: recession & {$[24-26]$} \\
\hline \multirow{3}{*}{$\begin{array}{l}\text { E: attitude } \\
\text { towards } \\
\text { foreigners }\end{array}$} & E1: hostility to foreigners & {$[5]$} \\
\hline & E2: confiscation or expropriation & {$[26]$} \\
\hline & $\begin{array}{l}\text { E3: discrimination against foreign } \\
\text { companies }\end{array}$ & {$[5,27]$} \\
\hline \multirow{3}{*}{$\begin{array}{l}\text { F: international } \\
\text { interactive } \\
\text { relations }\end{array}$} & F1: external conflicts & {$[3,9]$} \\
\hline & F2: international economic crisis & {$[3,9,26]$} \\
\hline & F3: external interferences & {$[3,9,28]$} \\
\hline \multirow{3}{*}{ G: low exposure } & G1: low attribute exposure & [17] \\
\hline & G2: low strategy exposure & {$[17]$} \\
\hline & G3: low transaction exposure & {$[17]$} \\
\hline \multirow{3}{*}{$\begin{array}{l}\text { H: capability } \\
\text { of enterprises }\end{array}$} & H1: core competitive capacity & [17] \\
\hline & $\mathrm{H} 2$ : relative bargain capacity & {$[17]$} \\
\hline & H3: integrate adaptive capacity & {$[17]$} \\
\hline \multirow{3}{*}{$\begin{array}{l}\text { I: risk } \\
\text { consequences }\end{array}$} & I1: profits & {$[5,7]$} \\
\hline & I2: stability and sustainability & {$[5,7]$} \\
\hline & I3: safety & {$[5,7]$} \\
\hline
\end{tabular}

politics, law, economy, and security. However, these studies mainly focused on the political risks in international general business [30]. The relationships among the political risk factors and consequences have not been examined in the context of international construction projects. After a comprehensive literature review, 18 hypothesized political risk paths in international construction projects were proposed (Figure 1), which will be tested in this study.

\section{Research Methods}

3.1. Date Collection. To verify whether the 18 proposed political risk paths are significant in international construction projects, a structured questionnaire was developed to collect the political risk cases from CCEs performing international construction projects. The questionnaires were composed of three parts: (1) the basic data of respondents (firm, work experience, title, and location); (2) the data related to the characteristics of the respondents' firms and projects they participated in G1-G3 and $\mathrm{H} 1-\mathrm{H} 3$; and (3) the data associated with the political risk cases (risk events, date, and I1-I3).
According to the previous study, the aforementioned factors can be measured by a list of observed indicators [17]. To avoid ambiguity and ensure respondents have accuracy in replying to questions, the brief introduction of political risk and the quantitative standard of each indicator were also attached to the questionnaire. For example, the score of "low attribute exposure" (G1) equals to the weighted average score of 5 items: "public opposition to the project," "project size," "prioritized of the project location," "technical and managerial complexity of the project," and "misconduct of contractors." All the items were measured in a relative way. For instance, the contract amount was a proxy of "project size," which was positively correlated with the political risk level. The projects with different contract amount were given the scores from 1 to 5 , where $5=$ the largest contract amount and $1=$ the smallest contract amount.

To collect political risk cases, all the Chinese practitioners who have experience in overseas construction business were considered as the target of the survey. By reviewing the websites, reports and publications of CCEs, economic counsellor's office of the Chinese Embassy, Chinese construction management research sector, and alumni association, a list of selected practitioners was developed, which contains 1000 senior managers, project managers, and project engineers.

From December 2015 to March 2016, a total of 1000 questionnaires were disseminated to the selected practitioners and 264 valid responses were received, representing a response rate of $26.4 \%$. A valid response refers to the questionnaire that includes one political risk case, and all the questions were completed and appropriately filled out. As indicated in Table 2, 67.4\% respondents were from the CCEs that were selected from the 2015 top 250 international contractors according to ENR's report, and $32.6 \%$ respondents were from other CCEs; $19.7 \%$ respondents were senior managers, and $80.3 \%$ respondents were project managers or project engineers. All the respondents had over 5 years of work experience, and 68 respondents had over 20 years of work experience. Among the 264 respondents, 113 were from Asia, 101 from Africa, and the other 40 from Oceania, Europe, and South America.

Apart from the data collected from the questionnaire, the matched data on the factors in groups $\mathrm{A}$ to $\mathrm{H}$ were collected from various secondary sources-the country report from the Chinese Ministry of Commerce (F2 and F3), the operational risk model from the Economist Intelligence Unit (EIU) (A2, B1-B5, C1-C5, D1-D4, and E1-E3), and the International Country Risk Guide (ICRG) from the PRS Group (A1, A3, and F1). All data with different dimensions were converted to the scale of 0 to 1 .

3.2. Structural Equation Modeling (SEM). Structural equation modeling (SEM) is a multivariate statistical analysis method that has been widely used to analyze the structural relationship between measured variables and latent constructs $[31,32]$. This method is the combination of confirmatory factor analysis (CFA), path analysis, partial least squares path modeling, and latent growth modeling [33]. 


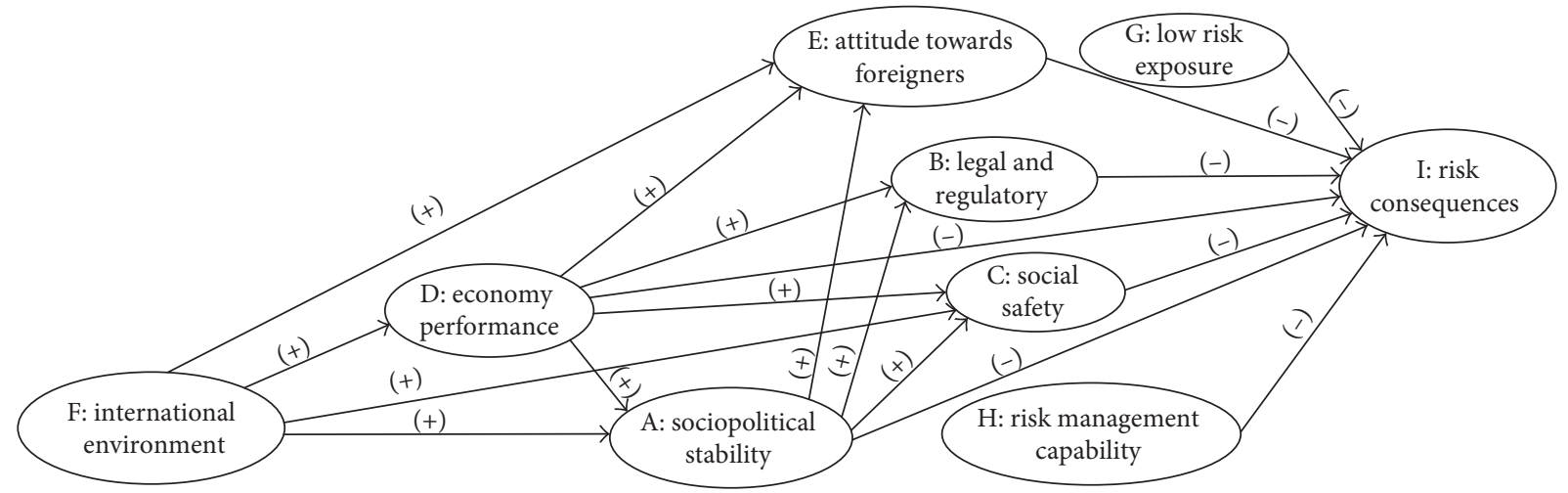

(+) indicates the positive correlation between two groups

(-) indicates the negative correlation between two groups

Figure 1: Hypotheses of the political risk paths.

TABLE 2: Profile of the respondents.

\begin{tabular}{lccc}
\hline Characteristics & Categorization & $N$ & $\%$ \\
\hline \multirow{2}{*}{ Enterprise scale } & ENR top 250 & 178 & 67.4 \\
& Others & 86 & 32.6 \\
\hline \multirow{3}{*}{ Job title } & Senior manager & 52 & 19.7 \\
& Project manager & 164 & 62.1 \\
& Project engineer & 48 & 18.2 \\
\hline \multirow{3}{*}{ Work experience } & $5-10$ & 89 & 33.7 \\
& $11-15$ & 79 & 30.0 \\
& $16-20$ & 68 & 25.8 \\
& Over 20 years & 28 & 10.6 \\
\hline \multirow{4}{*}{ Location } & Asia & 113 & 42.8 \\
& Oceania & 13 & 4.9 \\
& Africa & 101 & 38.3 \\
& Europe & 6 & 2.3 \\
& North America & 5 & 1.9 \\
& South America & 26 & 9.8 \\
\hline
\end{tabular}

SEM consists of the measurement model and the structural model. The measurement model expresses the relationships between the latent variables and their measures (observed variables). The structural model examines the relationships among latent variables [34]. Compared with other multivariate analysis methods, SEM has the superiority of (1) estimating multiple and interrelated dependence relationships, (2) representing unobserved concepts in these relationships, (3) testing measurement errors in estimates, and (4) defining a model explaining an entire set of relationships $[35,36]$.

In view of the aforementioned advantages, the SEM technology was applied to test the hypotheses of this study. First, CFA was conducted with the measurement model to test whether the nine groups can be measured by the 29 political risk factors and 3 political risk consequences. In the measurement model, the 29 political risk factors and 3 political risk consequences were viewed as 32 observed variables and the nine groups were viewed as the nine latent variables. After the measurement model was reliable and valid with a good goodness of fit, the path analysis was conducted with the structural model to test the hypothesized relationships among the nine latent variables.
Generally, the reliability and validity of the measurement model were measured by the following methods: the factor loadings $\geq 0.500$, the composite reliability (CR) value $\geq 0.70$, the average variance extracted (AVE) value $\geq 0.500$, and correlation between any two groups $\leq$ the square root of the AVEs of them [37-39]. In the structural model, the significance of the direct relationship between two latent variables is determined by the $t$-value for a two-tailed test (with $\geq 1.650$ representing the significance at the $p=0.10$ level, $\geq 1.960$ representing the significance at the $p=0.05$ level, and $\geq 2.580$ representing the significance at the $p=0.01$ level) $[40,41]$.

\section{Results}

4.1. Results of CFA. Before confirmatory factor analysis, the Cronbach alpha values of the nine groups were measured to test the data's reliability. All of them had the Cronbach alpha values greater than 0.700 , indicating the received data are sufficiently reliable [38].

In the progress of model measurement and modification, "speediness of judicial process" (B5) and "kidnapping or extortion" (C5) were removed due to their low values of factor loading. As shown in Tables 3 and 4, the factor loading of remaining 30 factors ranges from 0.712 to $0.903(\geq 0.500)$, the $\mathrm{CR}$ of the nine groups ranges from 0.829 to 0.914 $(\geq 0.500$ ), the AVE of the nine groups ranges from 0.548 to 0.726 ( $\geq 0.500$ ), and no correlation between any two groups is higher than the square root of the AVEs of them, which provided the evidence of discriminant validity of the groups. Thus, the final measurement model was reliable and valid for the structural model.

4.2. Results of Path Analysis. The hypothesized causal relationships among the nine groups were tested by the structural model. As shown in Table 5, among the 18 hypothesized political risk paths, 14 political risk paths were supported and other four political risk paths were not supported. Clearly, "D $\rightarrow A$, ," $D \rightarrow B$," " $D \rightarrow C$," "A $\rightarrow B$," "A $\rightarrow$ C," "B $\rightarrow I$," and "C $\rightarrow I$ " were significant at the $p=0.01$ level; " $\mathrm{E} \rightarrow \mathrm{I}$," 
TABLe 3: Measurement model evaluation.

\begin{tabular}{|c|c|c|c|c|}
\hline Factors & Factor loading & $R^{2}$ & $\mathrm{CR}$ & AVE \\
\hline A1 & 0.712 & 0.507 & & \\
\hline A2 & 0.751 & 0.564 & & \\
\hline \multirow[t]{2}{*}{ A3 } & 0.816 & 0.513 & & \\
\hline & & & 0.804 & 0.579 \\
\hline B1 & 0.827 & 0.684 & & \\
\hline B2 & 0.752 & 0.566 & & \\
\hline B3 & 0.870 & 0.757 & & \\
\hline \multirow[t]{2}{*}{ B4 } & 0.781 & 0.610 & & \\
\hline & & & 0.883 & 0.654 \\
\hline $\mathrm{C} 1$ & 0.813 & 0.564 & & \\
\hline $\mathrm{C} 2$ & 0.817 & 0.513 & & \\
\hline $\mathrm{C} 3$ & 0.903 & 0.815 & & \\
\hline \multirow[t]{2}{*}{$\mathrm{C} 4$} & 0.735 & 0.540 & & \\
\hline & & & 0.890 & 0.671 \\
\hline D1 & 0.756 & 0.572 & & \\
\hline D2 & 0.846 & 0.716 & & \\
\hline D3 & 0.912 & 0.832 & & \\
\hline \multirow[t]{2}{*}{ D4 } & 0.887 & 0.787 & & \\
\hline & & & 0.914 & 0.726 \\
\hline E1 & 0.774 & 0.599 & & \\
\hline E2 & 0.821 & 0.674 & & \\
\hline \multirow[t]{2}{*}{ E3 } & 0.843 & 0.711 & & \\
\hline & & & 0.854 & 0.661 \\
\hline $\mathrm{F} 1$ & 0.825 & 0.681 & & \\
\hline $\mathrm{F} 2$ & 0.777 & 0.604 & & \\
\hline \multirow[t]{2}{*}{ F3 } & 0.756 & 0.572 & & \\
\hline & & & 0.829 & 0.619 \\
\hline G1 & 0.855 & 0.731 & & \\
\hline G2 & 0.732 & 0.536 & & \\
\hline \multirow[t]{2}{*}{ G3 } & 0.821 & 0.674 & & \\
\hline & & & 0.846 & 0.647 \\
\hline $\mathrm{H} 1$ & 0.811 & 0.658 & & \\
\hline $\mathrm{H} 2$ & 0.792 & 0.627 & & \\
\hline \multirow[t]{2}{*}{ H3 } & 0.866 & 0.750 & & \\
\hline & & & 0.863 & 0.678 \\
\hline I1 & 0.783 & 0.613 & & \\
\hline $\mathrm{I} 2$ & 0.899 & 0.808 & & \\
\hline \multirow[t]{2}{*}{$\mathrm{I} 3$} & 0.836 & 0.699 & & \\
\hline & & & 0.878 & 0.707 \\
\hline
\end{tabular}

" $\mathrm{G} \rightarrow \mathrm{I}$," and " $\mathrm{H} \rightarrow \mathrm{I}$ " were significant at the $p=0.05$ level; "A $\rightarrow \mathrm{I}$," "F $\rightarrow \mathrm{C}$," "F $\rightarrow \mathrm{D}$," and " $\mathrm{D} \rightarrow \mathrm{I}$ " were significant at the $p=0.10$ level; and " $\mathrm{D} \rightarrow \mathrm{E}$," " $\mathrm{F} \rightarrow \mathrm{A}$," " $\mathrm{F} \rightarrow \mathrm{D}$," and " $\mathrm{F} \rightarrow \mathrm{E}$ " were not significant. Among the 8 factors, 7 (A, B, C, D, E, G, and $\mathrm{H}$ ) had the directly negative effect on "risk consequences" (I), and 3 (A, D, and F) had the indirectly negative effect on "risk consequences," indicating that the poor performance of those factors was associated with increased political risk.

\section{Discussion}

5.1. Sociopolitical Stability. "Sociopolitical stability" (A) was reflected by three factors with significant loading: "government stability" (A1), "factional conflicts" (A2), and "religious and ethnic tensions" (A3). The results showed that "sociopolitical stability" (A) had a positive effect on "legal and regulatory" (B) and "public safety" (C) and a negative effect on "risk consequences" (I). The finding was in line with the study maintaining that the poor performance of sociopolitical stability has both the directly and indirectly negative influence on international construction projects [7]. On the one hand, government instability can result in repudiation or breach of a specified commitment by the host government to the guarantee holder; on the other hand, sociopolitical instability can cause an abrupt change of laws or regulations, poor enforceability of contracts, and deterioration of safety conditions $[18,42]$ and thereby influence the projects under consideration. The continuous conflicts between different political groups, religions, and nationalities might trigger chaos of economy, law, and order [18], which in turn detrimentally affect the business activities [19]. Moreover, the host government plays the dominant role in the social security governance; thus, an unstable government is utterly incompetent to create a secure environment for international investors [43]. Furthermore, the relationship between "sociopolitical stability" (A) and "international environment" (F) was not significant. The reason is that sociopolitical stability is mainly determined by the national conditions of host countries without the tremendous changes in the international political, economic, and social circumstance.

It is crucial for ICEs to evaluate the sociopolitical stability of the target market before they enter a country [44]. In countries with sociopolitical instability, ICEs should keep low involvement with the political and religious groups to avoid getting involved in the conflict. Choosing sole venture projects or joint venture projects with short durations can help ICEs reduce their exposure to environmental fluctuations [7, 45]. Besides, obtaining the corresponding guarantee, buying risk insurance, and constantly monitoring evolving conditions are useful to deal with negative political events $[44,46]$.

5.2. Legal and Regulatory. "Legal and regulatory" (B) was estimated by three factors with significant loading: "poor enforcement mechanisms" (B1), "policy uncertainty" (B2), "unfairness of judicial process" (B3), and "price controls" (B4). "Legal and regulatory" (B) had a significantly negative effect on "risk consequences" (I). ICEs operating in countries with the unsound legal and regulatory may suffer from the risks related to improper construction procedures, illegal bid activities, illegal interferences, breach of contracts, and frequent change of the law [4, 7]. Regarded as complicated trading and involving the benefits of multiparties, international construction business requires the criterion and guarantee of the legal and regulatory [20]. However, in some countries, the poor enforcement mechanisms and unfairness of judicial process make ICEs difficult to safeguard their legitimate rights and interests in resolving disputes. ICEs will be restless and adrift in the countries with unfair price controls and vague laws and regulations. When the law lost its function of guidance and evaluation, the demarcation of legal or illegal has become unclear, people cannot logically predict their own 
TABLE 4: Discriminant validity of the nine groups.

\begin{tabular}{|c|c|c|c|c|c|c|c|c|c|}
\hline Grouping & $\mathrm{A}$ & $B$ & $\mathrm{C}$ & $\mathrm{D}$ & $\mathrm{E}$ & $\mathrm{F}$ & $\mathrm{G}$ & $\mathrm{H}$ & I \\
\hline A & 0.761 & - & - & - & - & - & - & - & - \\
\hline B & 0.598 & 0.809 & - & - & - & - & - & - & - \\
\hline $\mathrm{C}$ & 0.472 & 0.253 & 0.819 & - & - & - & - & - & - \\
\hline $\mathrm{D}$ & 0.607 & 0.446 & 0.589 & 0.852 & - & - & - & - & - \\
\hline $\mathrm{E}$ & 0.135 & 0.067 & 0.051 & 0.097 & 0.813 & - & - & - & - \\
\hline F & 0.112 & 0.077 & 0.406 & 0.264 & 0.321 & 0.787 & - & - & - \\
\hline G & 0.131 & 0.118 & 0.109 & 0.165 & 0.098 & 0.035 & 0.804 & - & - \\
\hline $\mathrm{H}$ & 0.056 & 0.312 & 0.211 & 0.236 & 0.178 & 0.263 & 0.089 & 0.823 & - \\
\hline I & -0.178 & -0.473 & -0.289 & -0.335 & -0.097 & -0.125 & -0.238 & -0.343 & 0.841 \\
\hline
\end{tabular}

Note. Bolded numbers are the square root of the AVEs.

TABle 5: Path coefficients and significance.

\begin{tabular}{lccc}
\hline Path & Coefficient & $t$-value & Interpretation \\
\hline $\mathrm{F} \rightarrow \mathrm{A}$ & 0.097 & 1.116 & Not supported \\
$\mathrm{F} \rightarrow \mathrm{C}$ & $0.265^{*}$ & 1.894 & Supported \\
$\mathrm{F} \rightarrow \mathrm{D}$ & $0.278^{*}$ & 1.713 & Supported \\
$\mathrm{F} \rightarrow \mathrm{E}$ & 0.134 & 1.332 & Not supported \\
$\mathrm{D} \rightarrow \mathrm{A}$ & $0.484^{* * *}$ & 5.389 & Supported \\
$\mathrm{D} \rightarrow \mathrm{B}$ & $0.567^{* * *}$ & 6.258 & Supported \\
$\mathrm{D} \rightarrow \mathrm{C}$ & $0.632^{* * *}$ & 10.021 & Supported \\
$\mathrm{D} \rightarrow \mathrm{E}$ & 0.175 & 1.602 & Not supported \\
$\mathrm{D} \rightarrow \mathrm{I}$ & $-0.248^{*}$ & 1.753 & Supported \\
$\mathrm{A} \rightarrow \mathrm{B}$ & $0.611^{* * *}$ & 9.876 & Supported \\
$\mathrm{A} \rightarrow \mathrm{C}$ & $0.445^{* * *}$ & 6.214 & Supported \\
$\mathrm{A} \rightarrow \mathrm{E}$ & 0.123 & 0.935 & Not supported \\
$\mathrm{A} \rightarrow \mathrm{I}$ & $-0.235^{*}$ & 1.851 & Supported \\
$\mathrm{B} \rightarrow \mathrm{I}$ & $-0.373^{* * *}$ & 4.712 & Supported \\
$\mathrm{C} \rightarrow \mathrm{I}$ & $-0.328^{* * *}$ & 3.351 & Supported \\
$\mathrm{E} \rightarrow \mathrm{I}$ & $-0.246^{* *}$ & 2.393 & Supported \\
$\mathrm{G} \rightarrow \mathrm{I}$ & $-0.289^{* *}$ & 2.351 & Supported \\
$\mathrm{H} \rightarrow \mathrm{I}$ & $-0.257^{* *}$ & 1.989 & Supported \\
\hline
\end{tabular}

Note. ${ }^{*}$ Path is significant at the $p=0.10$ level. ${ }^{* *}$ Path is significant at the $p=0.05$ level. ${ }^{* * *}$ Path is significant at the $p=0.01$ level.

consequence of action according to law, and the market will be plunged into confusion [21,22].

ICEs should act strictly according to the local law to avoid the unnecessary disputes caused by their own mistakes. Keeping good relationships with host governments and powerful groups are helpful for ICEs to obtain more support and benefits (e.g., convenient approval procedures, less government intervention, unblocked information and communication channels, and sufficient government guarantees) [3]. Furthermore, the skills and experience of local partners (e.g., lawyers, subcontractors, suppliers, and agencies) would be effective assistances for ICEs to safeguard their rights and interests under the unfamiliar legal conditions $[47,48]$.

5.3. Social Safety. Four factors had high loadings on "social safety" (C): "crime" (C1), "terrorism" (C2), "violent demonstrations" (C3), and "armed conflicts" (C4). The results showed that "social safety" (C) had a remarkable negative influence on "risk consequences" (I). Security is essential for international business activities. An unsafe environment will bring tremendous threats to the personnel and property safety of international contractors [4, 23]. Over past few decades, ICEs have been plagued with the political risks aroused from social safety around the world, such as the armed conflicts in Yemen, Honduras, Syria, Afghanistan, and Libya; the terrorist attacks in Mali, Iraq, and India; the kidnappings in southern Sudan, Pakistan, and Somalia. Thus, how to ensure security becomes a difficult issue which various ICEs need to solve.

Formulating emergency plan and providing staff for selfprotection training are important for ICEs in an unsafe country $[44,49]$. Closed management of construction sites with security systems (e.g., security guards, monitoring devices, and alarm mechanisms) might be helpful for ICEs to isolate crime, terrorist attacks, violent demonstrations, and armed conflicts [4]. Under the severe security situation, such as armed conflicts, wars, and terrorist attacks, ICEs should stop construction and evacuate from the danger area immediately.

5.4. Economy Performance. "Economy performance" (D) contained four factors with significant loading: "inflation" (D1), "unemployment" (D2), "exchange rate volatility" (D3), and "recession" (D4). "Economy performance" (D) was identified as a critical political risk factor that had a positive effect on "sociopolitical stability" (A), "legal and regulatory" (B), and "public safety" (C) and a negative effect on "risk consequences" (I). Poor economic performance can cause not only macroeconomic risk but also social and political unrest, which in turn detrimentally affect the international construction projects [29]. During the time of inflation, the purchasing power of currency will decline, imposing a cost on those ICEs who have used the fixed price contract. In general, ICEs are paid in local currency or hard currency and adverse volatility of exchange rate and interest rate would bring huge losses to ICEs [50]. In some countries, the high unemployment rate and inflation rate act as two important drivers for sociopolitical instability [24, 25]. In addition, most studies support the notion that social safety has a clear relationship with the economy performance. A long period of the depression can result in the disorder in both social value and the morality, and further intensify the society contradiction and the occurrence of crime [51].

Diversified investing in different countries can reduce firm risk [52]. In the countries with the high level of 
macroeconomic risk, ICEs should adopt appropriate contracts (e.g., escalation lump sum and cost-plus-fixed fee) to transfer the risks to owners [53]. When ICEs have some unavoidable risks, retaining the premium for those risks is an available strategy to reduce potential losses [54]. Furthermore, ICEs must constantly pay attention to the volatility of prices and hoard material in anticipation of inflation.

5.5. Attitude towards Foreigners. "Attitude towards foreigners" (E) was estimated by three factors with strong loading: "hostility to foreigners" (E1), "confiscation or expropriation" (E2), and "discrimination against foreign companies" (E3). It is identified that "attitude towards foreigners" (E) had a significantly negative effect on "risk consequences" (I). Meanwhile, the relationships between "attitude towards foreigners" (E) and "economy performance" (D), "international environment" (F) and "sociopolitical stability" (A) were not remarkable. The reason is that "attitude towards foreigners" (E) can be treated as an independent factor in these political risk cases, which has no regular pattern within different social cultural systems. There will be more obstacles and threats (e.g., public opposition, riots, political interference, and unjust treatment) for ICEs in those countries with racism and xenophobia. Furthermore, the attitude of the government to foreigners has a strong relationship with foreign policymaking [55]. The unfavorable foreign policy made by host governments can be regarded as a signal of various risks such as confiscation or expropriation, foreign investment restrictions, land ownership restrictions, unfair compensation, foreign exchange restrictions, and capital restrictions.

ICEs can preferentially access to the countries that have good relations with their home countries to seek more recognition and less opposition [4]. Localization strategies (e.g., tying-up with local businesses, forming a joint venture with local contractors, and employing the natives) would be helpful for ICEs to blur their image as foreigners, and thereby reduce their probability of being treated with discrimination and opposition [8, 44]. Moreover, participating in local public welfare activities, cultivating a good image via propaganda, beneficent to environment protection, and abiding by the local culture can help ICEs obtain social recognition, resources, opportunities, and support and further to achieve value creation in the host country.

5.6. International Environment. "International environment" (F) encompassed three factors with high loading: "external conflicts" (F1), "international economic crisis" (F2), and "external interferences" (F3). As shown in Figure 2, "international environment" (F) had a significant positive effect on "social safety" (C) and "economy performance" (D), but an insignificant effect on "sociopolitical stability" (A) and "attitude towards foreigners" (E). The results indicating that the unstable international environment has the capacity to affect the economy and safety of most countries. External conflicts (e.g., latent conflict, manifest conflict, crisis, severe crisis, and wars) can potentially destabilize the social safety of host countries [28]. International economic crisis and external interferences (e.g., foreign pressures, economic sanctions, embargoes, and international boycotts) would result in host countries' economy depression [6, 24, 30].

ICEs should always pay close attention to the changes in the international situation and adjust their operation strategies and project plans accordingly. Furthermore, establishing strong business councils and associations would be helpful to improve enterprises' existence ability.

5.7. Low Exposure. Three factors were strongly related to "low exposure" (G): "low attribute exposure" (G1), "low strategy exposure" (G2), and "low transaction-based exposure" (G3). "Low exposure" (G) was confirmed having a significantly negative effect on "risk consequences" (I). Attribute-based exposure would be related to the characteristics of projects and ICEs, such as longer duration, lower technical complexity and managerial complexity of projects, and misconduct of enterprises [50]. Strategy-based exposure may be related to the smaller size of subsidiary or enterprise, and unreasonable arrangements of leverage choice and ownership. Transaction-based exposure would be related to lower project desirability to the host country, insufficient external funding of the project, and disadvantageous conditions of the contract. The ICEs with lower risk exposure would have a higher capability to mitigate uncertainties $[17,56]$.

It is necessary for ICEs to reduce their risk exposure in high risk areas. The available strategies that help ICEs reduce risk exposure include: avoiding misconduct, choosing suitable entry mode and projects, allocating extra funds, and obtaining the corresponding guarantee.

5.8. Capability of Enterprises. Three factors were involved in "capability of enterprise" $(\mathrm{H})$ with strong loadings: "core competitive capacity" (H1), "relative bargain capacity" (H2), and "integrate adaptive capacity" (H3). "Capability of enterprises" $(\mathrm{H})$ had a significantly negative effect on "risk consequences" (I). A higher risk response capability of an ICE indicates that it has higher viability in an uncertain environment and is less likely to suffer damage arising from political risk [17]. Core competitive capacities include rich experience, high localization, and stable relationships with host governments and power groups. The ICEs with superior core competitive capacities are regarded to have excellent viability and superior profitability [57]. Relative bargain capacity is related to the technology or resources that are needed by the host governments. The ICEs with the higher bargain capacity are expected to get advantageous terms of the contract [58]. Integrate adaptive capacities include high involvement of local business interests, adaptive organizational culture, and significant economic contribution to the local economy. The ICEs with greater integrate adaptive capacities would be more acceptable for the host governments and the society $[29,59]$.

The cultivation of capability is a long-term process for ICEs. Fortunately, ICEs can make up their own weakness and thereby improve their corresponding capabilities by choosing the right partners. 


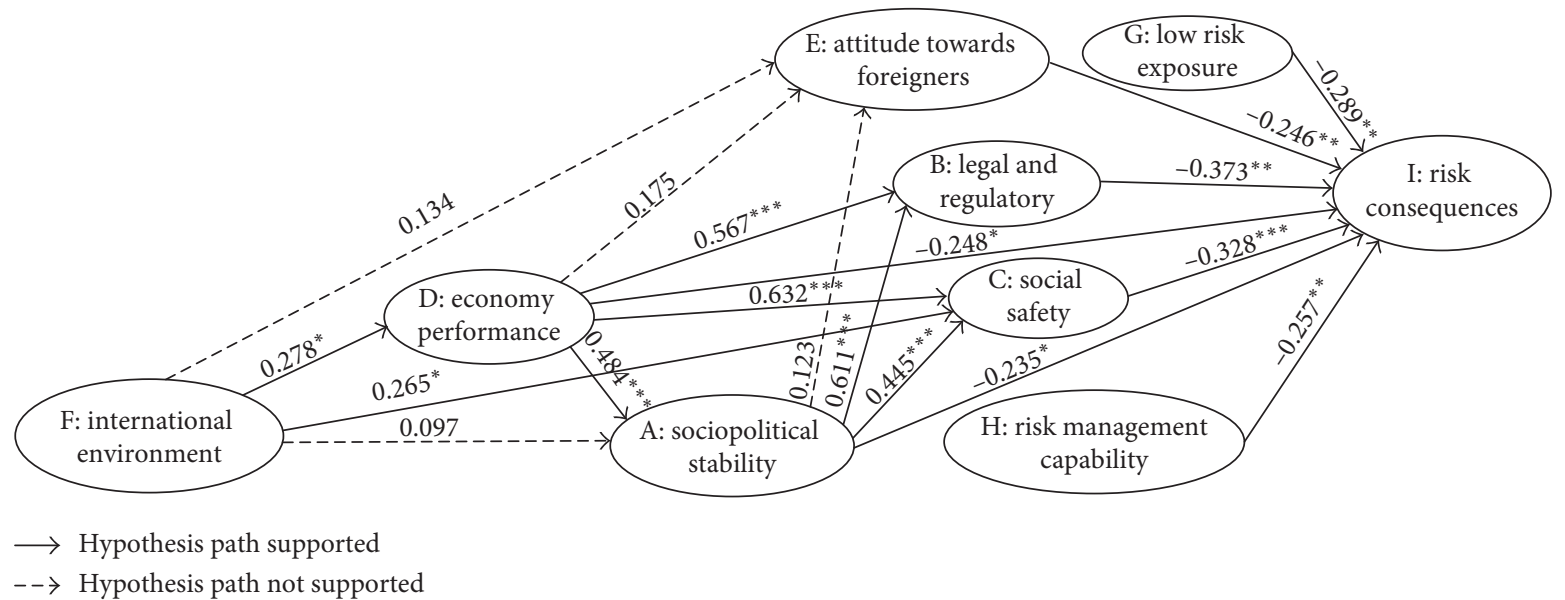

Figure 2: Networking of political risk paths. ${ }^{*}$ Significance at the $p=0.10$ level, ${ }^{* *}$ significance at the $p=0.10$ level, and ${ }^{* * *}$ significance at the $p=0.10$ level.

5.9. Risk Consequences. "Risk consequences" (I) was measured by three factors with high loading: "profits" (I1), "stability and sustainability" (I2), and "safety" (I3). As illustrated in Figure 2, "risk consequences" (I) was significantly influenced by "sociopolitical stability" (A), "legal and regulatory" (B), "social safety" (C), "economy performance" (D), "attitude towards foreigners" (E), "low exposure" (G3), and "capability of enterprises" (H) and indirectly influenced by "international environment" (F). These findings support the standpoint that the political risk level of international construction projects are not only influenced by the fluctuations in the external environment, but also affected by the characteristics of projects and firms [17].

While political risk is difficult to forecast and eliminate, it can be moderately addressed by reducing the risk exposure of the project system and improving the capability of enterprises. Successful political risk management is dependent on sufficient resources and information [60]. Political risk not only affects the performance of international construction projects, but also affects the objectives of ICEs (e.g., financial, reputation, stability, survival, development, and strategic decision) $[3,9,61]$. Thus, ICEs should treat political risk as part of the entire risk portfolio and address it across multiple business areas. Generally, political risk management in international constriction projects should (1) be based on a comprehensive understanding of political risks; (2) be treated as an important component of the decision-making process; (3) emphasize both the projects' short-term and enterprises' long-term goals; and (4) be continually enhanced with the accumulation and sharing of risk management experience.

\section{Conclusions}

This study attempted to explore the political risk paths in international construction projects. Based on the 264 political risk cases collected from 30 CCEs performing international construction projects, a total of 8 political risk factors and 14 significant political risk paths were identified. Consistent with previous studies, the macrofactors ("sociopolitical stability" (A), "legal and regulatory" (B), "social safety" (C), "economy performance" (D), "attitude towards foreigners" (E), and "international environment" $(\mathrm{F})$ ) were associated with the external threats in the overseas construction market. The microfactors ("low exposure" (G) and "capability of enterprises" $(\mathrm{H})$ ) were related to the internal vulnerability project systems. Among the 8 factors, 7 ( $A, B, C, D, E, G$, and $H$ ) had the directly negative effect on "risk consequences" (I) and 3 (A, D, and F) had the indirectly negative effect on "risk consequences." Based on the understanding of the effects of these political risk factors, the coping strategies, for example, choosing a suitable entry mode, choosing suitable projects, maintaining good relations with powerful groups and host governments, diversification investing in different countries, obtaining the corresponding guarantee, buying risk insurance, adopting perfect contract, employing capable local partners, implementing a localization strategy, making contingency plans, sending staff to training programs, and allocating extra funds, were developed for ICEs to address the political risk in the global market.

The practical implications that can be drawn from this study are as follows:

(1) ICEs should be sensitive to those political risk factors and take them as the indicators for political risk assessment.

(2) Since political risk in international construction projects is not only influenced by the external threats, but also affected by the internal vulnerabilities, ICEs can moderately address political risk by reducing risk exposure of the project system and improving their capability.

(3) ICEs should realize that political risk at the project level can also affect enterprise's objectives (e.g., financial, reputation, stability, survival, and development) and conduct political risk management practices at both the project and firm level and link risk management strategies to the enterprise's objectives. 
(4) ICEs should suit their political risk management strategies to different conditions in terms of locality, time, issue, and people involved.

The primary limitation of this study is that most of the political risk cases (in total $81.1 \%$ ) were collected from the projects located in Africa and Asia, but relatively few were collected from other overseas markets. According to the ENR's report, Africa and Asia have been the two largest overseas markets of CCEs in recent years. Therefore, the region distribution of the samples is consistent with the distribution of the projects performed by CCEs. Due to the inability to predict before the survey whether the practitioners would be willing to participate in the survey, the received political risk cases can be regarded as a nonprobabilistic sample, which has been recognized as the representative sample [62]. Despite the limitation, the practical implications of this study are not limited in CCEs because the situations in the global market are generally the same for all ICEs. Therefore, it is believed that this study makes a significant contribution to the knowledge of political risk management in the international construction business.

Further research would be conducted to examine the political risk management strategies in different enterprises and different countries to increase the practical validity.

\section{Data Availability}

The data of the 264 political risk cases used to support the findings of this study are available from the corresponding author upon request.

\section{Conflicts of Interest}

The authors declare that they have no conflicts of interest.

\section{Acknowledgments}

This study was supported by the National Natural Science Foundation of China (NSFC-71372199 and 71771052) and the Postgraduate Research and Practice Innovation Program of Jiangsu Province, China (KYCX17-0191 and KYLX16-0303).

\section{References}

[1] X. Zhao, B. G. Hwang, and S. P. Low, "Critical success factors for enterprise risk management in Chinese construction companies," Construction Management and Economics, vol. 31, no. 12, pp. 1199-1214, 2013.

[2] R. Jia, Q. Li, X. Deng, X. Zhao, and J. Yuan, "Entry mode taxonomy and choice of Chinese international construction companies," Journal of Management in Engineering, vol. 33, no. 3, article 0000506, 2016.

[3] S. Q. Wang, R. L. K. Tiong, S. K. Ting, and D. Ashley, "Political risk: analysis of key contract clauses in China's BOT project," Journal of Construction Engineering and Management, vol. 125 , no. 3, pp. 190-197, 1999.

[4] T. Chang, X. Deng, J. Zuo, and J. Yuan, "Political risks in central Asian countries: factors and strategies," Journal of
Management in Engineering, vol. 34, no. 2, article 04017059, 2018.

[5] D. B. Ashley and J. J. Bonner, "Political risks in international construction," Journal of Construction Engineering and Management, vol. 113, no. 3, pp. 447-467, 1987.

[6] A. Al Khattab, J. Anchor, and E. Davies, "Managerial perceptions of political risk in international projects," International Journal of Project Management, vol. 25, no. 7, pp. 734-743, 2007.

[7] X. Deng and S. P. Low, "Exploring critical variables that affect political risk level in international construction projects: case study from Chinese contractors," Journal of Professional Issues in Engineering Education and Practice, vol. 140, no. 1, article 04013002, 2014.

[8] J. J. Bonner, Political Risk Analysis System for Multinational Contractors, Massachusetts Institute of Technology, Cambridge, MA, USA, 1981.

[9] X. Deng and S. P. Low, "Understanding the critical variables affecting the level of political risks in international construction projects," KSCE Journal of Civil Engineering, vol. 17, no. 5, pp. 895-907, 2013.

[10] R. A. Aliber, "Exchange risk, political risk and investor demands for external currency deposits," Journal of Money, Credit and Banking, vol. 7, no. 2, pp. 161-179, 1975.

[11] L. Zhuang, R. Ritchie, and Q. Zhang, "Managing business risks in China," Long Range Planning, vol. 31, no. 4, pp. 606-614, 1998.

[12] S. H. Robock, "Political risk: identification and assessment," Columbia Journal of World Business, vol. 6, no. 4, pp. 6-20, 1971.

[13] S. H. Robock and K. Simmonds, International Business and Multinational Enterprises, Irwin, Homewood, IL, USA, 1989.

[14] X. Zhao, B. G. Hwang, and Y. Gao, "A fuzzy synthetic evaluation approach for risk assessment: a case of Singapore's green projects," Journal of Cleaner Production, vol. 115, pp. 203-213, 2016.

[15] J. Jakobsen, "Old problems remain, new ones crop up: political risk in the 21 st century," Business Horizons, vol. 53, no. 5, pp. 481-490, 2010.

[16] M. C. Tsai and C. H. Su, "Political risk assessment of five East Asian ports-the viewpoints of global carriers," Marine Policy, vol. 29, no. 4, pp. 291-298, 2005.

[17] X. Deng, S. P. Low, and X. Zhao, "Project system vulnerability to political risks in international construction projects: the case of Chinese contractors," Project Management Journal, vol. 45, no. 2, pp. 20-33, 2014.

[18] A. Annett, "Social fractionalization, political instability, and the size of government," IMF Staff Papers, vol. 48, no. 3, pp. 561-592, 2001.

[19] M. Hastak and A. Shaked, "ICRAM-1: model for international construction risk assessment," Journal of Management in Engineering, vol. 16, no. 1, pp. 59-69, 2000.

[20] C. R. Williamson, "Informal institutions rule: Institutional arrangements and economic performance," Public Choice, vol. 139, no. 3-4, pp. 371-387, 2009.

[21] H. Farrell and J. Knight, "Trust, institutions, and institutional change: industrial districts and the social capital hypothesis," Politics and Society, vol. 31, no. 4, pp. 537-566, 2003.

[22] A. N. Rao, J. L. Pearce, and K. Xin, "Governments, reciprocal exchange and trust among business associates," Journal of International Business Studies, vol. 36, no. 1, pp. 104-118, 2005. 
[23] F. Y. Y. Ling and V. T. P. Hoang, "Political, economic, and legal risks faced in international projects: case study of Vietnam," Journal of Professional Issues in Engineering Education and Practice, vol. 136, no. 3, article 0000015, 2010.

[24] L. Bing, R. L. K. Tiong, W. F. Wong, and D. Chew, "Risk management in international construction joint ventures," Journal of construction engineering and management, vol. 125, no. 4, pp. 277-284, 1999.

[25] Y. Y. Ling and S. P. Low, "Legal risks faced by foreign architectural, engineering, and construction firms in China," Journal of Professional Issues in Engineering Education and Practice, vol. 133, no. 3, pp. 238-245, 2007.

[26] J. De La Torre and D H. Neckar, "Forecasting political risks for international operations," International Journal of Forecasting, vol. 4, no. 2, pp. 221-241, 1988.

[27] J. Van Wyk, "Political sources of international business risk: an interdisciplinary framework," Journal of International Business Research, vol. 9, no. 1, pp. 103-119, 2010.

[28] J. D. Simon, "A theoretical perspective on political risk," Journal of International Business Studies, vol. 15, no. 3, pp. 123-143, 1984.

[29] G. Rice and E. Mahmoud, "Political risk forecasting by Canadian firms," International Journal of Forecasting, vol. 6, no. 1, pp. 89-102, 1990.

[30] A. Yaprak and KT. Sheldon, "Political risk management in multinational firms: an integrative approach," Management Decision, vol. 22, no. 6, pp. 53-67, 1984.

[31] J. Liu, X. Zhao, and Y. Li, "Exploring the factors inducing contractors' unethical behavior: case of China," Journal of Professional Issues in Engineering Education and Practice, vol. 143, no. 2, article 0000316, 2016.

[32] K. Cho, T. Hong, and C. Hyun, "Effect of project characteristics on project performance in construction projects based on structural equation model," Expert Systems with Applications, vol. 36, no. 7, pp. 10461-10470, 2009.

[33] M. Shan, Y. Le, K. T. Yiu, A. P. Chan, and Y. Hu, "Investigating the underlying factors of corruption in the public construction sector: Evidence from China," Science and engineering ethics, vol. 23, no. 6, pp. 1643-1666, 2017.

[34] B. M. Byrne, Structural Equation Modeling with AMOS: Basic Concepts, Applications, and Programming, Routledge, New York, NY, USA, 2010.

[35] B. Xiong, M. Skitmore, B. Xia, M. A. Masrom, K. Ye, and A. Bridge, "Examining the influence of participant performance factors on contractor satisfaction: a structural equation model," International Journal of Project Management, vol. 32, no. 3, pp. 482-491, 2014.

[36] G. X. Chen, M. Shan, A. P. Chan, X. Liu, and Y. Q. Zhao, "Investigating the causes of delay in grain bin construction projects: the case of China," International Journal of Construction Management, vol. 26, no. 4, pp. 1-14, 2017.

[37] C. Fornell and D. F. Larcker, "Evaluating structural equation models with unobservable variables and measurement error," Journal of Marketing Research, vol. 18, no. 1, pp. 39-50, 1981.

[38] H. Doloi, K. C. Iyer, and A. Sawhney, "Structural equation model for assessing impacts of contractor's performance on project success," International Journal of Project Management, vol. 29, no. 6, pp. 687-695, 2011.

[39] J. F. Hair, R. E. Anderson, R. L. Tatham, and W. C. Black, Multivariate Data Analysis, Prentice-Hall, London, UK, 5th edition, 1998.
[40] T. F. Ong and G. Musa, "Examining the influences of experience, personality and attitude on SCUBA divers' underwater behaviour: a structural equation model," Tourism Management, vol. 33, no. 6, pp. 1521-1534, 2012.

[41] J. F. Hair, C. M. Ringle, and M. Sarstedt, "PLS-SEM: indeed a silver bullet," Journal of Marketing theory and Practice, vol. 19, no. 2, pp. 139-152, 2011.

[42] J. Aron, "Growth and institutions: a review of the evidence," World Bank Research Observer, vol. 15, no. 1, pp. 99-135, 2000.

[43] Y. Y. Ling and L. Hoi, "Risk faced by Singaporean firms when undertaking construction projects in India," International Journal of Project Management, vol. 24, no. 3, pp. 261-270, 2006.

[44] X. Deng, S. P. Low, Q. Li, and X. Zhao, "Developing competitive advantages in political risk management for international construction enterprises," Journal of Construction Engineering and Management, vol. 140, no. 9, article 04014040, 2014.

[45] I. Alon and M. A. Martin, "A normative model of macro political risk assessment," Multinational Business Review, vol. 6, no. 2, pp. 10-19, 1998.

[46] J. Jakobsen, Political Risk and the Multinational Company, Tapir Academic Press, Trondheim, Norway, 2012.

[47] S. P. Low and H. B. Jiang, "Internationalization of Chinese construction enterprises," Journal of Construction Engineering and Management, vol. 129, no. 6, pp. 589-598, 2004.

[48] C. M. Chan and S. Makino, "Legitimacy and multi-level institutional environments: implications for foreign subsidiary ownership structure," Journal of International Business Studies, vol. 38, no. 4, pp. 621-638, 2007.

[49] N. Lee and J. E. Schaufelberger, "Risk management strategies for privatized infrastructure projects: study of the buildoperate-transfer approach in East Asia and the Pacific," Journal of Management in Engineering, vol. 30, no. 3, article 0000225, 2013.

[50] I. Alon and T. Herbert, "A stranger in a strange land: micro political risk and the multinational firm," Business Horizons, vol. 52, no. 2, pp. 127-137, 2009.

[51] J. L. Butkiewicza and H. Yanikkaya, "The impact of sociopolitical instability on economic growth: analysis and implications," Journal of Policy Modeling, vol. 27, no. 5, pp. 629-645, 2005.

[52] D. R. Lessard, "World, country, and industry relationships in equity returns: implications for risk reduction through international diversification," Financial Analysts Journal, vol. 32, no. 1, pp. 32-38, 1976.

[53] S. Q. Wang, M. F. Dulaimi, and M. Y. Aguria, "Risk management framework for construction projects in developing countries," Construction Management and Economics, vol. 22, no. 3, pp. 237-252, 2004.

[54] B. Akinci and M. Fischer, "Factors affecting contractors' risk of cost overburden," Journal of Management in Engineering, vol. 14, no. 1, pp. 67-76, 1998.

[55] B. Toyne and P. Walters, Global Marketing Management, Allyn \& Bacon, Boston, MA, USA, 2nd edition, 1993.

[56] X. Deng, S. P. Low, X. Zhao, and T. Chang, "Identifying micro variables contributing to political risks in international construction projects," Engineering, Construction and Architectural Management, vol. 25, no. 3, pp. 317-334, 2018.

[57] S. H. Han and J. E. Diekmann, "Approaches for making riskbased go/no-go decision for international projects," Journal of 
Construction Engineering and Management, vol. 127, no. 4, pp. 300-308, 2001.

[58] R. Ramamurti, "The obsolescing "bargaining model?" MNChost developing country relations revisited," Journal of International Business Studies, vol. 32, no. 1, pp. 23-39, 2001.

[59] S. P. Low and Y. Shi, "Cultural influences on organizational processes in international projects: two case studies," Work Study, vol. 50, no. 6, pp. 267-285, 2001.

[60] M. Leitch, "ISO 31000: 2009—the new international standard on risk management," Risk analysis, vol. 30 , no. 6, pp. 887892, 2010.

[61] T. Chang, B. G. Hwang, X. Deng, and X. Zhao, "Identifying political risk management strategies in international construction projects," Advances in Civil Engineering, vol. 2018, Article ID 1016384, 11 pages, 2018.

[62] J. R. Wilkins, "Construction workers' perceptions of health and safety training programmes," Construction Management and Economics, vol. 29, no. 10, pp. 1017-1026, 2011. 


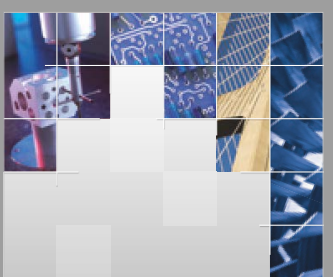

\section{Enfincering}
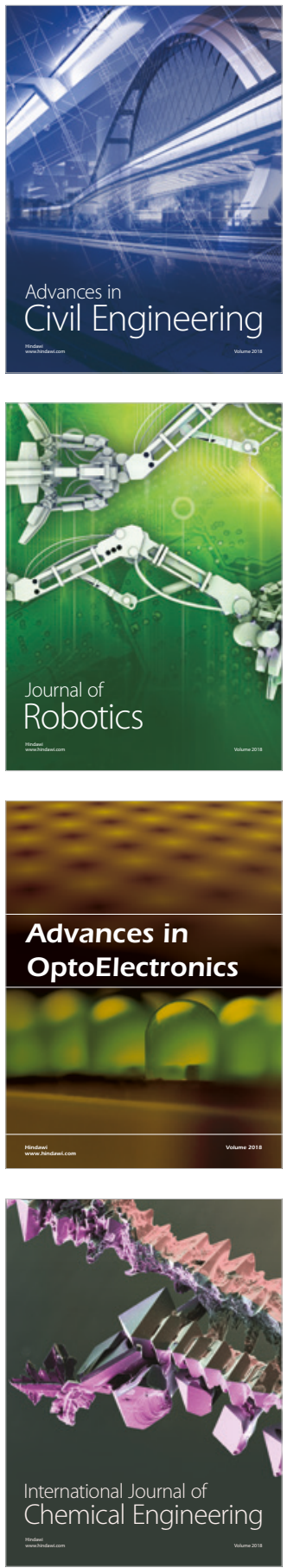

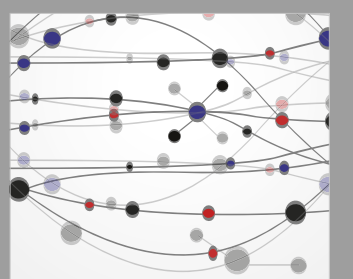

\section{Rotating \\ Machinery}

The Scientific World Journal

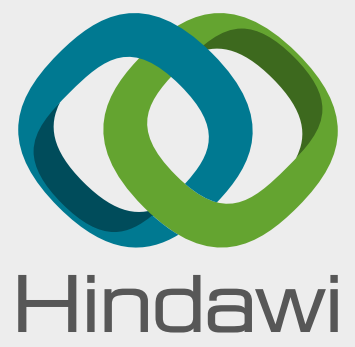

Submit your manuscripts at

www.hindawi.com
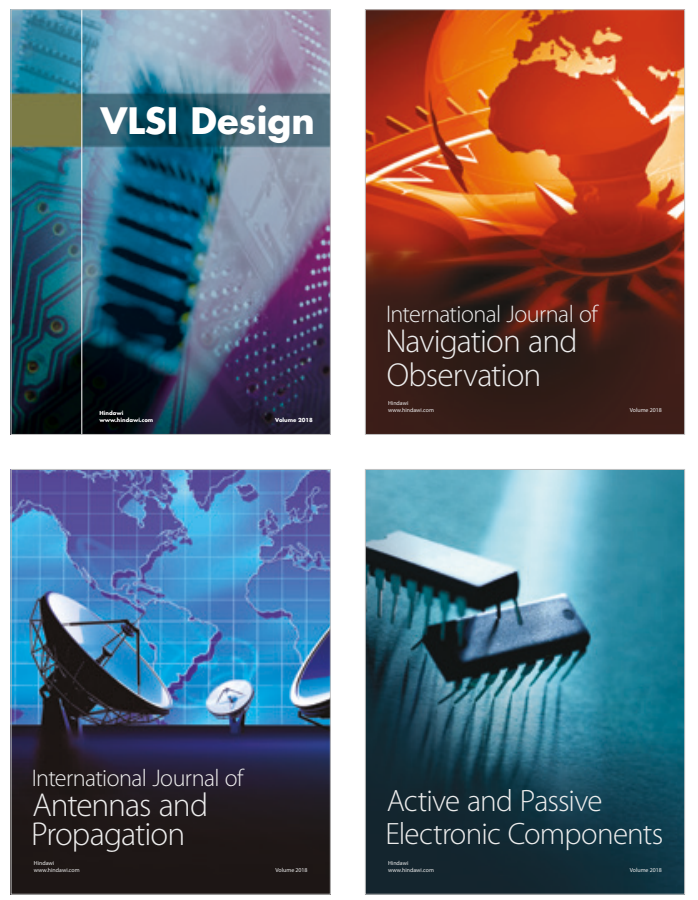
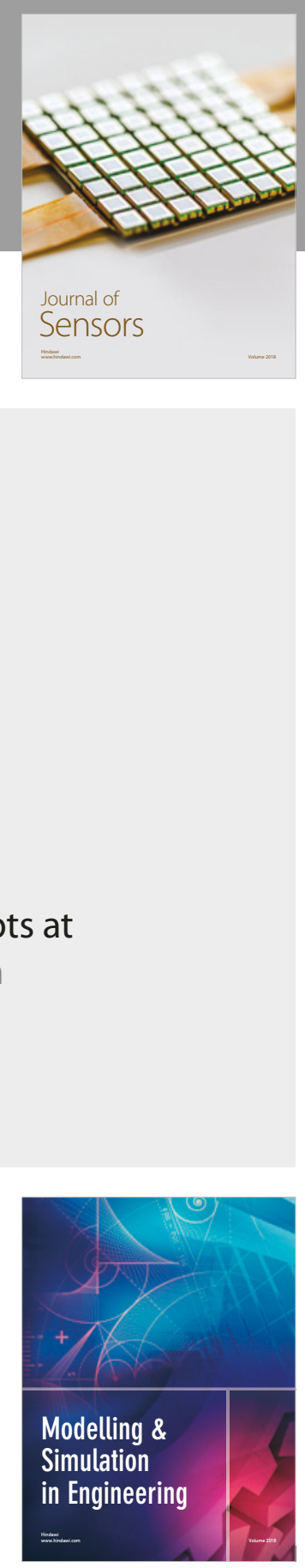

\section{Advances \\ Multimedia}
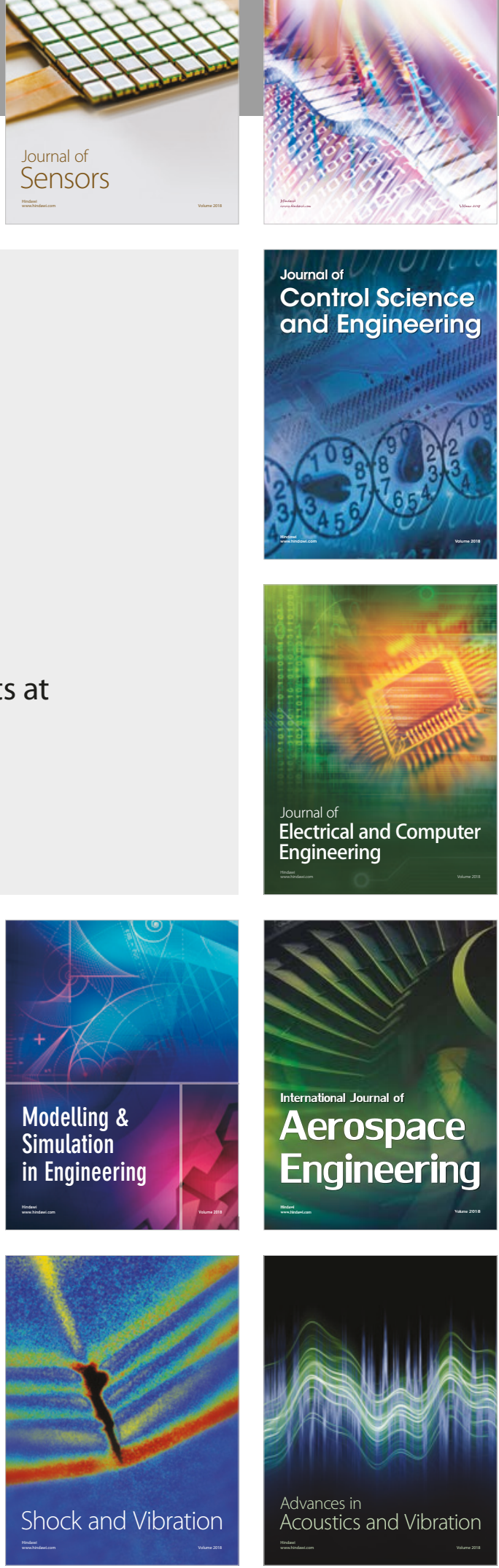